Review article

\title{
A BRIEF REVIEW ON THE MODE OF ACTION OF ANTINEMATODAL DRUGS
}

\author{
ABONGWA Melanie, MARTIN Richard J., ROBERTSON Alan P.* \\ Department of Biomedical Sciences, College of Veterinary Medicine, Iowa State University, Ames, \\ IA 50011, USA
}

(Received 01 May, Accepted 24 May 2017)

Anthelmintics are some of the most widely used drugs in veterinary medicine. Here we review the mechanism of action of these compounds on nematode parasites. Included are the older classes of compounds; the benzimidazoles, cholinergic agonists and macrocyclic lactones. We also consider newer anthelmintics, including emodepside, derquantel and tribendimidine. In the absence of vaccines for most parasite species, control of nematode parasites will continue to rely on anthelmintic drugs. As a consequence, vigilance in detecting drug resistance in parasite populations is required. Since resistance development appears almost inevitable, there is a continued and pressing need to fully understand the mode of action of these compounds. It is also necessary to identify new drug targets and drugs for the continued effective control of nematode parasites.

Key words: anthelmintic, parasite, benzimidazoles, avermectins, cholinergic, emodepside, derquantel

\section{INTRODUCTION}

Anthelmintics are drugs that are used to treat infections caused by parasitic worms (helminths) [1]. There are three major groups of helminths namely: nematodes (roundworms), trematodes (flukes) and cestodes (tapeworms). These groups of helminths are divided into two phyla; nematodes (roundworms) and platyhelminths (trematodes and cestodes) [2]. Anthelmintics either kill worms or cause their expulsion from the body, without causing any significant damage to the host [3]. Although there is a high prevalence of parasitic worms, the progress of anthelmintic drug discovery and development by pharmaceutical companies has been slow over the years. One contributing factor is that the majority of those suffering from helminth infections live in developing nations who lack the resources to support a profitable drug market [4]. Development of new anthelmintics is limited by high costs and modest global markets for antiparasitic drugs and chemicals. The cost of development of a new

\footnotetext{
*Corresponding author: e-mail: alanr@iastate.edu
} 
drug is estimated at US $\$ 400$ million for livestock use, and more than US $\$ 800$ million for human use. The global market for antiparasitic drugs and chemicals are estimated at US $\$ 12$ billion for plant pathogens, $\$ 11$ billion for livestock and companion animals, and $\$ 0.5$ for human health [5-8]. Many anthelmintic drugs used to treat humans were first developed and marketed as veterinary drugs [9-11]. There are only a few classes of anthelmintics including; benzimidazoles, imidazothiazoles, tetrahydopyrimidines, macrocyclic lactones, amino-acetonitrile derivatives, spiroindoles and cyclooctadepsipeptides. Here we review the mode of action of several classes of drug used to treat infections with parasitic nematodes.

\section{Benzimidazoles (BZs)}

Thiabendazole was the first benzimidazole anthelmintic agent produced. Since the introduction of thiabendazole in 1961, a number of benzimidazoles with improved efficacy and extended spectrum of action have been developed [12]. These include mebendazole, albendazole and flubendazole (Figure 1). The initial mode of action of benzimidazoles was thought to be inhibition of various parasite metabolic enzymes including fumarate reductase and malate dehydrogenase $[13,14]$. However, it is now established that benzimidazoles selectively bind with high affinity to parasite $\beta$-tubulin and inhibit microtubule polymerization. This results in the destruction of cell structure and consequent death of the parasite [15].

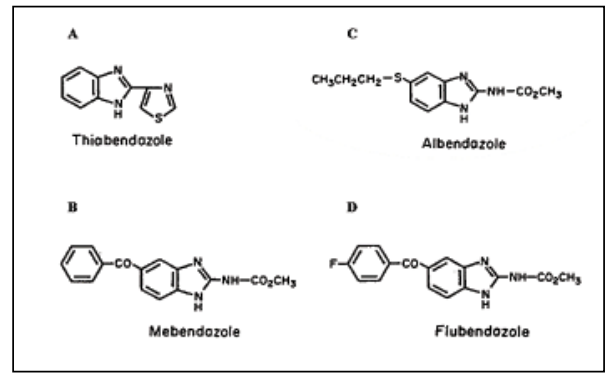

Figure 1. Chemical structures of thiabendazole (A), mebendazole (B), albendazole (C) and flubendazole (D). From [12].

\section{Imidazothiazoles}

Imidazothiazoles act as nicotinic acetylcholine receptor (nAChR) agonists. They bind to nAChRs on body wall muscles, causing spastic paralysis of the worm, and hence, its expulsion from the host [16]. Tetramisole (Figure 2), an aminothiazol derivative, was the first member of this class of anthelmintics, and constitutes a racemic mixture of 50\% L- or S- and D- or R-isomers [17-19]. The L-isomer was later demonstrated to be more potent than the racemic mixture or the D-isomer [20,21]. Consequently, the D-isomer was removed from the racemic mixture and this led to the development of the L-isomer as levamisole. The detailed mode of action of levamisole, the only existing drug in this class, has been carefully studied at the single-channel level in nematode body wall muscles [22-24]. Robertson and Martin [24], showed using the 
patch-clamp technique that at the single-channel level in $A$. suum muscles, levamisole $(1-90 \mu \mathrm{M}$ concentrations) causes activation of cation-selective channels, in addition to voltage-sensitive open channel-block and desensitization. The mean open-times for single-channel currents activated by levamisole were $0.80-2.85 \mathrm{~ms}$ and the conductance levels were $19-46 \mathrm{pS}$, with a mean of $32.9 \pm 1.23 \mathrm{pS}$. This corresponded to the levamisole-sensitive, L-subtype $\mathrm{nAChR}$ with a channel conductance of $35 \mathrm{pS}$, as revealed by Qian et al. [22]. Robertson et al. [23], later revealed the presence of a similar nAChR subtype in levamisole-sensitive $O$. dentatum muscle patches which was absent in the levamisole-resistant muscle patches. In subsequent oocyte expression studies, the reconstituted O. dentatum L-subtype nAChR (UNC-29, UNC-38, UNC-63 and ACR-8) was preferentially sensitive to levamisole and also had a single-channel conductance of $\sim 35 \mathrm{pS}$ [25]. Levamisole not only causes spastic paralysis but it also stimulates egglaying in wild-type C. elegans [26].

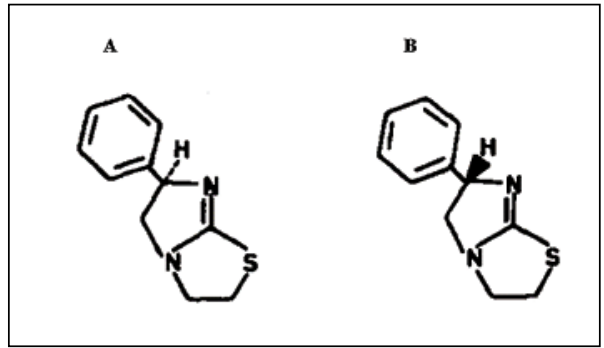

Figure 2. Chemical structures of R (+)-tetramisole (A) and S (-)-tetramisole (levamisole) (B). From [21].

\section{Tetrahydropyrimidines}

Tetrahydropyrimidines share a similar mode of action to imidazothiazoles and are commonly grouped together as nicotinic agonists $[27,28]$. Examples of this anthelmintic drug class include pyrantel, oxantel and morantel (Figure 3). Pyrantel is an imidazothiazole-derived tetrahydropyrimidine that was discovered in 1966 as an anthelmintic agent with broad spectrum activity against roundworms and hookworms in domestic animals [29,30]. Pyrantel however lacks activity against whipworms [31]. Studies on the mode of action of pyrantel at the single-channel level identified the L-subtype $\mathrm{nAChR}$ in $A$. suum as also preferentially activated by pyrantel [32]. Pyrantel, like levamisole, also causes open channel-block [33]. Although not characterized at the single-channel level, the $O$. dentatum nAChR receptor subunits UNC-29, UNC38 and UNC-63 reconstitute a pyrantel/tribendimidine- but not levamisole-sensitive nAChR subtype in X. laevis oocytes [25]. The search for an agent with activity against whipworms led to the development of oxantel, an m-oxyphenol derivative of pyrantel [31]. Contrary to pyrantel, oxantel preferentially activates the N-subtype nAChRs in A. suum [34]. Oxantel, like levamisole and pyrantel, also causes open channel-block in A. suum [35]. Morantel is a methyl ester analog of pyrantel which also targets the L-subtype $\mathrm{nAChR}$ in $A$. sum $[36,37]$. At the single-channel level, morantel causes the activation and block of this receptor subtype [38]. Recently, morantel was shown to act 
as an agonist of the nAChR subtype comprising ACR-26/ACR-27 subunits from $H$. contortus or Parascaris equorum expressed in X. laevis oocytes [39]. In oocyte expression studies, morantel was seen to cause a non-competitive voltage-sensitive open channel block of the newly characterized $A$. sum ACR-16 receptor [40].

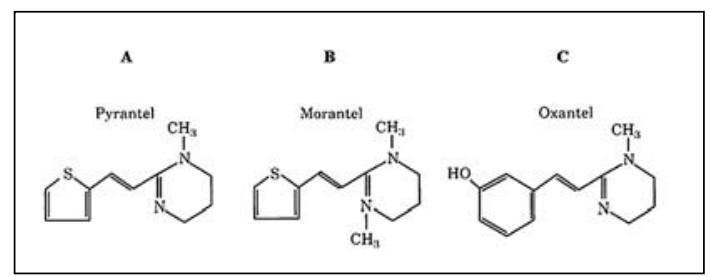

Figure 3. Chemical structures of pyrantel (A), morantel (B) and oxantel (C). From [28].

\section{Macrocyclic lactones (MLS)}

Macrocyclic lactones (avermectins and milbemycins) are a group of chemical compounds derived from soil microorganisms of the genus Streptomyces [41-43]. MLs were introduced in the 1980s as antiparasitic agents with broad spectrum activity against nematodes and arthropods $[44,45]$. Examples of commercially available avermectins are ivermectin, abamectin, doramectin and selamectin, while milbemycin oxime and moxidectin, are examples of commercially available milbemycins (Figure 4). MLs are selective agonists of glutamate-gated chloride channels (GluCls) which are present in neurons and pharyngeal muscles of nematodes and arthropods, but absent in humans. ML activation of GluCls inhibits movement and pharyngeal pumping [46,47]. In addition to $\mathrm{GluCl}$ effects, the avermectins also act as antagonists of 4-aminobutyric acid (GABA) and nicotinic receptors expressed on somatic muscle cells of parasitic nematodes [48-50]. Ivermectin, the first member of the avermectins, although originally developed as a veterinary drug, was later approved for use in humans for the control of onchocerciasis and lymphatic filariasis [9-11,51]. Also, ivermectin was shown to act as an irreversible agonist of recombinant human glycine receptors at higher concentrations $(>0.3 \mu \mathrm{M})$, but at lower concentrations $(30 \mathrm{nM})$, it acted as a positive allosteric modulator [52]. Ivermectin showed a similar positive allosteric modulation effect on the vertebrate neuronal $\alpha 7$ nicotinic acetycholine receptor [53].

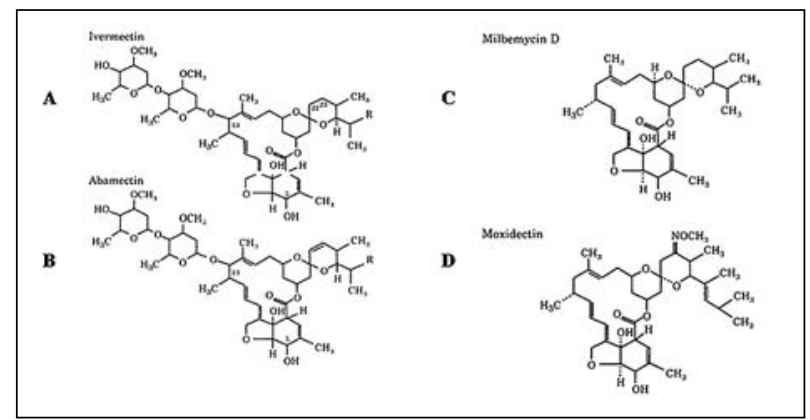

Figure 4. Chemical structures of ivermectin (A), abamectin (B), milbemycin D (C) and moxidectin (D). From [28]. 


\section{Amino-acetonitrile derivatives (AADs)}

The AADs are a new class of synthetic anthelmintics with broad spectrum activity against nematodes that are resistant to the benzimidazoles, imidazothiazoles and macrocyclic lactones [54-56]. Monepantel, also known as AAD 1556, is the first member of this class to be developed for the control of a broad range of parasitic nemtaodes in sheep (Figure 5) [56]. Genetic screens of C. elegans identified ACR-23, which belongs to the nematode-specific DEG-3 subfamily of nAChRs, as the target of AADs [55]. Further studies on the mode of action of the AADs have led to the confirmation of ACR-23 as the principal target for monepantel in C. elegans, as well as the identification of other DEG-3-like nAChR target genes; H. contortus monepantel-1 (Hco-mptl-1, formerly Hc-acr-23), Hco-des-2, Hco-deg-3 and C. elegans acr-20 [57-60]. Baur et al., [57], also demonstrated that at low concentrations $(<1 \mathrm{nM})$, monepantel acts as a positive allosteric modulator of $H$. contortus MPTL-1 and C. elegans ACR-20 receptors, and at high concentrations $(>0.1 \mu \mathrm{M})$, it acts as a direct agonist of these receptors. In a different study, monepantel by itself did not activate $H$. contortus DEG-3/DES-2 receptors expressed in $X$. laevis oocytes, but did cause a potentiation in the receptors' current responses when co-applied with choline [61].

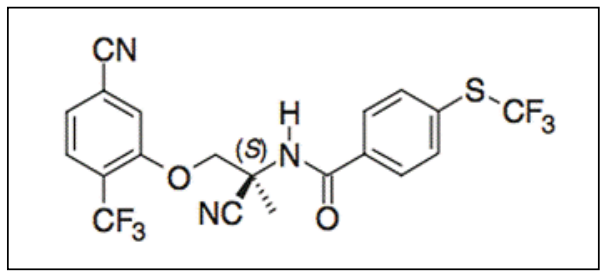

Figure 5. Chemical structure of monepantel. From [56].

\section{Spiroindoles}

Derquantel (2-deoxy-paraherquamide or PNU-141962) is the first semi-synthetic member of this new class of anthelmintics (Figure 6) [62,63]. Derquantel which is also the first commercial member of the spiroindoles, was introduced in 2010 for use in combination with the macrocyclic lactone, abamectin, under the trade name STARTECT $^{\circledR}$, for the control of parasitic nematodes in sheep. Derquantel acts as an antagonist of nAChRs to cause flaccid paralysis which results in the expulsion of parasites from the host [64]. The combination of derquantel and abamectin has an excellent broad spectrum efficacy against several parasitic nematodes in sheep, including those resistant to benzimidazoles, levamisole and macrocyclic lactones $[63,65]$. The efficacy of the derquantel and abamectin combination has also been shown in muscle contraction and electrophysiological studies on $A$. sum muscle flaps. Derquantel or abamectin alone inhibited responses to acetylcholine, and the inhibition was greater when a combination of derquantel and abamectin was used, producing a synergistic (greater than additive) effect [50]. Also, the derquantel and abamectin combination was shown to produce a greater inhibition of acetylcholine- or pyantel-induced current responses from expressed pyrantel/tribendimidine $O$. dentatum receptors compared to 
derquantel or abamectin alone [48]. The introduction of combination anthelmintics provides a useful tool to increase anthelmintic drug efficacy, overcome resistance to other anthelmintic classes and delay resistance development [66,67].

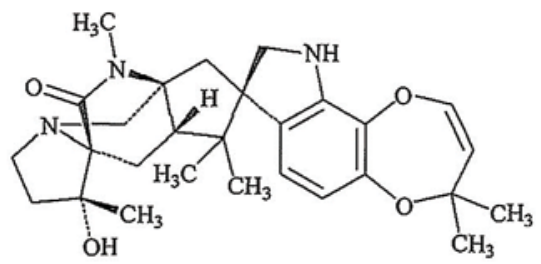

Figure 6. Chemical structure of derquantel. From [63].

\section{Cyclooctadepsipeptides}

Cyclooctadepsipeptides were discovered in the early 1990s. In 1992, PF1022A, the parent compound, was isolated from the fungus, Mycelia sterilia, which grows on the leaves of the plant, Camellia japonica [68]. PF1022A is made up of four N-methyl-Lleucine, two D-lactate and two D-phenyllactate residues that are arranged as a cyclic octadepsipeptide with an alternating L-D-L configuration (Figure 7) [69]. Emodepside, formerly PF1022-221 and BAY 44-4400, is a semisynthetic derivative of PF1022A, produced by attaching a morpholine ring at the para position of the two D-phenyllactic acids [70]. This modification resulted in improved pharmacokinetic properties. The anthelmintic potential of PF1022A and emodepside has been reported in numerous in vitro and in vivo studies [71-76]. Interestingly, PF1022A and emodepside have a broad spectrum of activity against several nematode species including those that are resistant to benzimidazoles, levamisole and ivermectin [77]. This indicated that the mode of action of the cyclooctadepsipeptides is different and that this class of anthelmintics possess 'resistance-busting' properties.

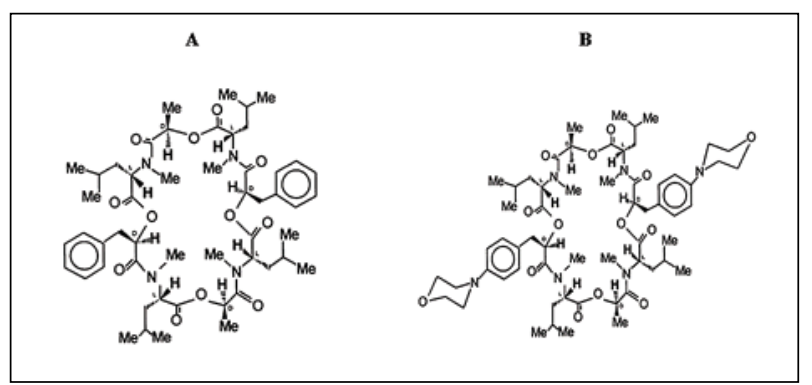

Figure 7. Chemical structures of PF1022A (A) and emodepside (B). From [69].

Studies on the mode of action suggest that emodepside targets the calcium-activated potassium channel (SLO-1), there is also evidence for the involvement of the latrophilin (LAT-1) receptor [78-80]. Mutagenesis screens in C. elegans revealed a lack of sensitivity of slo-1 null mutants to emodepside's inhibitory effects on locomotion 
and feeding. Inhibition of locomotion was achieved via the action of emodepside on SLO-1 expressed in body wall muscles or neurons, whereas inhibition of feeding was achieved via the action of emodepside on SLO-1 expressed in neurons but not muscle [81]. RNAi studies implicated a role for LAT-1 in mediating emodepside's inhibitory effect on pharyngeal pumping in the pharynx [81,82]. Guest et al. [81], showed C. elegans lat-1 null mutants had an estimated five-fold reduction in sensitivity to emodepside. These studies suggest that the inhibitory effect of emodepside on feeding is both SLO-1 and latrophilin-dependent. However, emodepside treatment inhibited locomotion in both wild type and lat-1:lat-2 null C. elegans, implying that the inhibitory effect of emodepside on locomotion is latrophilin-independent [81]. The sensitivity of nematode SLO-1 channels to calcium is different from that of insects and humans [83].

\section{Tribendimidine}

Tribendimidine is a symmetrical diamidine derivative of amidantel (Figure 8) [84]. It was developed in the mid 1980s by the National Institute of Parasitic diseases in Shanghai, China, as a broad spectrum anthelmintic drug [85]. In 2004, tribendimidine was approved by the Chinese Food and Drug Administration for treatment of helminth infections in humans [86]. It is the only new anthelmintic drug that has been approved for human use within the past 3 decades [87]. Tribendimidine has been shown in laboratory and clinical studies to have a broad spectrum of activity against several nematode, trematode and cestode species [84,88-92] . The activity of tribendimidine against 20 helminth parasites has been documented [93]. Earlier studies on the mode of action of tribendimidine in the nematode model $C$. elegans demonstrated that tribendimidine acts as an agonist of the L-subtype nAChR in this species, similar to levamisole and pyrantel [94]. Parasitic nematodes however, show different nAChR subtype selectivity from C. elegans, and this varies across nematode species. Buxton et al. [25], showed in oocyte expression studies that tribendimidine, just like pyrantel, is more selective for the reconstituted pyrantel/tribendimidine $\mathrm{nAChR}$ subtype comprising of UNC-29, UNC-38 and UNC-63 subunits from $O$. dentatum and had little or no effect on the levamisole-sensitive subtype. In $A$. suum, the action of tribendimidine is pharmacologically similar to that of bephenium rather than levamisole, leading to the conclusion that tribendimidine selectively acts on the bephenium-sensitive, B-nAChR

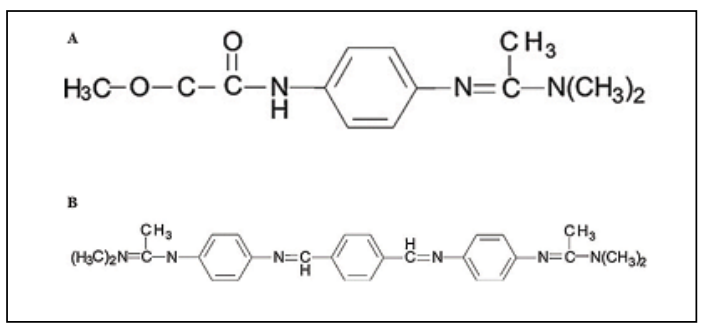

Figure 8. Chemical structures of amidantel (A) and tribendimidine (B). From [84]. 
subtype, not the L-subtype nAChR in Ascaris [95]. Robertson et al. (2015), further showed tribendimidine to cause a more potent inhibition of migration of $O$. dentatum levamisole-resistant larvae (LEVR) than levamisole-sensitive larvae (SENS). Thus, confirming their hypothesis that unlike in $C$. elegans, tribendimidine does not act on the L-subtype nAChR in parasitic nematodes.

\section{Anthelmintic resistance}

In broad terms, anthelmintic resistance is referred to as the decline in the efficacy of an anthelmintic drug in a population of parasites that were once susceptible to the drug. The repeated and improper use of currently available anthelmintics has led to the development of resistance in numerous veterinary parasite species worldwide, with increasing concerns that this may extend to human parasites [9698]. Since anthelmintics within each drug class act in a similar manner, resistance to one anthelmintic in a given drug class is likely to be accompanied by resistance to other anthelmintics of that same class (side resistance). There is also the likelihood for the development of cross resistance from anthelmintics of one drug class to those of another, if the two drug classes share similar targets [99]. Hence, the widespread occurrence of resistance across the majority of anthelmintic drug classes (Table 1). Sadly, the onset of anthelmintic resistance development can be rapid, thiabendazole resistance occurred 3 years after its introduction to the market [100].

Table 1. Anthelmintic resistance and mechanisms of resistance to the major anthelmintic drug classes. Modified from [101,107,108].

\begin{tabular}{|c|c|c|c|c|}
\hline Anthelmintic class & Host & $\begin{array}{c}\text { Year of } \\
\text { initial } \\
\text { approval }\end{array}$ & $\begin{array}{c}\text { Year of first } \\
\text { published report } \\
\text { of resistance }\end{array}$ & $\begin{array}{l}\text { Potential mechanism } \\
\text { of resistance }\end{array}$ \\
\hline \multicolumn{4}{|l|}{ Benzimidazoles } & \multirow{3}{*}{$\begin{array}{l}\text { Mutations in } \beta \text {-tubulin; } \\
\text { Phe200Try, Phe167Try } \\
\text { or Glu198Ala }\end{array}$} \\
\hline \multirow[t]{2}{*}{ Thiabendazole } & Sheep & 1961 & 1964 & \\
\hline & Horse & 1962 & 1965 & \\
\hline \multicolumn{4}{|c|}{ Imidothiazoles-tetrahydropyrimidines } & \multirow{3}{*}{$\begin{array}{l}\text { Changes in nicotinic } \\
\text { acetylcholine receptors }\end{array}$} \\
\hline Levamisole & Sheep & 1970 & 1979 & \\
\hline Pyrantel & Horse & 1974 & 1996 & \\
\hline \multicolumn{4}{|c|}{ Avermectin-mylbemicins } & \multirow{5}{*}{$\begin{array}{l}\text { Reduced sensitivity of } \\
\text { GluCl/GABA receptors }\end{array}$} \\
\hline Ivermectin & Sheep & 1981 & 1988 & \\
\hline \multirow{3}{*}{ Moxidectin } & Horse & 1983 & 2002 & \\
\hline & Sheep & 1991 & 1995 & \\
\hline & Horse & 1995 & 2003 & \\
\hline
\end{tabular}

Reports of resistance to anthelmintics in various parts of the world have been welldocumented [101-103]. In spite of the numerous reports of anthelmintic resistance, the mechanisms by which resistance occurs remain to be fully elucidated (Table 1). 
Resistance mechanisms include: (i) mutation or deletion of one or more amino acids in the target genes, (ii) reduction in the number of receptors, (iii) decreased affinity of receptors for drugs, and (iv) absence of bioactivating enzymes [104-108]. Management practices can also delay or overcome anthelmintic resistance. Anthelmintic resistance can be delayed or overcome by: (i) identifying new drug targets with different pharmacological profiles from those of existing drugs, (ii) introducing new anthelmintics with different modes of action from those of existing anthelmintics, (iii) combination therapy, with members of the combination from different drug classes, (iv) rotating drugs with different modes of action between dosing seasons, and (v) keeping some parasites in untreated refugia [109-111]. A detailed understanding of the biochemical and genetic basis of anthelmintic action is therefore imperative as this will allow for the development of sensitive assays for early detection, and hence more efficient management of anthelmintic resistance.

\section{DISCUSSION}

It is interesting to note, that with the exception of the benzimidazoles, the majority of antinematodal drugs act on ion channel proteins in the parasite. Given the number and diversity of predicted channel types in the parasite, it would seem reasonable to focus on these proteins as new drug targets. The success of the macrocyclic lactones led to a hiatus in new drug development to treat nematode infections. Fortunately, the arrival of compounds such as emodepside and derquantel seems to indicate this hiatus is coming to an end. However, the well recognized phenomenon of drug resistance remains a concern. Resistance can be slowed, for example by leaving a refugia of sensitive parasites or by using drug combinations with multiple mechanisms of action. However, there remains a compelling need to discover new compounds with new modes of action in timely manner.

\section{Acknowledgments}

The authors would like to acknowledge funding from NIH R21AI121831-01 to APR, NIH R01AI047194 to RJM and the Schlumberger Foundation Faculty for the Future Program to MA.

\section{Authors' contributions}

MA, RJM \& APR wrote the manuscript.

\section{Declaration of conflicting interests}

The author(s) declared no potential conflicts of interest with respect to the research, authorship, and/or publication of this article. 


\section{REFERENCES}

1. Holden-Dye L, \& Walker RJ: Avermectin and avermectin derivatives are antagonists at the 4-aminobutyric acid (GABA) receptor on the somatic muscle cells of Ascaris; is this the site of anthelmintic action? Parasitology 1990, 101 Pt 2: 265-271.

2. Hotez PJ, Brindley PJ, Bethony JM, King CH, Pearce EJ, Jacobson J: Helminth infections: the great neglected tropical diseases. J Clin Invest 2008, 118(4):1311-1321.

3. Martin RJ, Robertson AP, Bjorn H: Target sites of anthelmintics. Parasitology 1997, 114 Suppl: S111-124.

4. Pink R, Hudson A, Mouries MA, Bendig M: Opportunities and challenges in antiparasitic drug discovery. Nat Rev Drug Discov 2005, 4: 727-740.

5. DiMasi JA, Hansen RW, Grabowski HG: The price of innovation: new estimates of drug development costs. J Health Econ 2003, 22: 151-185.

6. Evans T, Chapple N: The animal health market. Nat Rev Drug Discov 2002, 1: 937-938.

7. Martin RJ, Robertson AP: Control of nematode parasites with agents acting on neuromusculature systems: lessons for neuropeptide ligand discovery. Adv Exp Med Biol 2010, 692: 138-154.

8. Morgan S, Grootendorst P, Lexchin J, Cunningham C, Greyson D: The cost of drug development: a systematic review. Health Policy 2011, 100: 4-17.

9. Crump A, Omura S: Ivermectin, 'wonder drug' from Japan: the human use perspective. Proc Jpn Acad Ser B Phys Biol Sci 2011, 87: 13-28.

10. Geary TG: Ivermectin 20 years on: maturation of a wonder drug. Trends Parasitol 2005, 21: 530-532.

11. Omura S: Ivermectin: 25 years and still going strong. Int J Antimicrob Agents 2008, 31: 91-98.

12. McKellar QA, Scott EW: The benzimidazole anthelmintic agents--a review. J Vet Pharmacol Ther 1990, 13: 223-247.

13. Prichard RK: Mode of action of the anthelminthic thiabendazole in Haemonchus contortus. Nature 1970, 228: 684-685.

14. Tejada P, Sanchez-Moreno M, Monteoliva M, Gomez-Banqueri H: Inhibition of malate dehydrogenase enzymes by benzimidazole anthelmintics. Vet Parasitol 1987, 24: 269-274.

15. Lacey E: Mode of action of benzimidazoles. Parasitol Today 1990, 6: 112-115.

16. Aceves J, Erlij D, Martinez-Maranon R: The mechanism of the paralysing action of tetramisole on Ascaris somatic muscle. Br J Pharmacol 1970, 38: 602-607.

17. Raeymaekers AH, Allewijn FT, Vandenberk J, Demoen PJ, Van Offenwert TT, Janssen PA: Novel broad-spectrum anthelmintics. Tetramisole and related derivatives of 6-arylimidazo[2,1-b]thiazole. J Med Chem 1966, 9: 545-551.

18. Raeymaekers AH, Roevens LF, Janssen PA: The absolute configurations of the optical isomers of the broad spectrum anthelmintic tetramisole. Tetrahedron Lett 1967, 16: 14671470.

19. Thienpont D, Vanparijs OF, Raeymaekers AH, Vandenberk J, Demoen JA, Allewijn FT, Marsboom RP, Niemegeers CJ, Schellekens KH, Janssen PA: Tetramisole (R 8299), a new, potent broad spectrum anthelmintic. Nature 1966, 209: 1084-1086.

20. Thienpont D, Brugmans J, Abadi K, Tanamal S: Tetramisole in the treatment of nematode infections in man. Am J Trop Med Hyg 1969, 18: 520-525. 
21. Van den Bossche H, Janssen PA: The biochemical mechanism of action of the anthelmintic drug tetramisole. Life Sci 1967, 6: 1781-1792.

22. Qian H, Martin RJ, Robertson AP: Pharmacology of N-, L-, and B-subtypes of nematode $\mathrm{nAChR}$ resolved at the single-channel level in Ascaris suum. FASEB J 2006, 20: 2606-2608.

23. Robertson AP, Bjorn HE, Martin RJ: Resistance to levamisole resolved at the single-channel level. FASEB J 1999, 13: 749-760.

24. Robertson SJ, Martin RJ: Levamisole-activated single-channel currents from muscle of the nematode parasite Ascaris suum. Br J Pharmacol 1993, 108: 170-178.

25. Buxton SK, Charvet CL, Neveu C, Cabaret J, Cortet J, Peineau N, Abongwa M, Courtot E, Robertson AP, Martin RJ: Investigation of acetylcholine receptor diversity in a nematode parasite leads to characterization of tribendimidine- and derquantel-sensitive nAChRs. PLoS Pathog 2014, 10: e1003870.

26. Trent C, Tsuing N, Horvitz HR: Egg-laying defective mutants of the nematode Caenorhabditis elegans. Genetics 1983, 104: 619-647.

27. Aubry ML, Cowell P, Davey MJ, Shevde S. Aspects of the pharmacology of a new anthelmintic: pyrantel. Br J Pharmacol 1970, 38: 332-344.

28. Martin RJ: Modes of action of anthelmintic drugs. Vet J 1997, 154: 11-34.

29. Austin WC, Courtney W, Danilewicz JC, Morgan DH, Conover LH, Howes HL, Jr., Lynch JE, McFarland JW, Cornwell RL, Theodorides VJ: Pyrantel tartrate, a new anthelmintic effective against infections of domestic animals. Nature 1966, 212: 1273-1274.

30. Howes HL, Jr., Lynch JE: Anthelmintic studies with pyrantel. I. Therapeutic and prophylactic efficacy against the enteral stages of various helminths in mice and dogs. J Parasitol 1967, 53: 1085-1091.

31. McFarland JW, Howes HL, Jr.: Novel anthelmintic agents. 6. Pyrantel analogs with activity against whipworm. J Med Chem 1972, 15: 365-368.

32. Martin RJ, Verma S, Levandoski M, Clark CL, Qian H, Stewart M., Robertson AP: Drug resistance and neurotransmitter receptors of nematodes: recent studies on the mode of action of levamisole. Parasitology 2005, 131 Suppl: S71-84.

33. Robertson SJ, Pennington AJ, Evans AM, Martin RJ: The action of pyrantel as an agonist and an open channel blocker at acetylcholine receptors in isolated Ascaris suum muscle vesicles. Eur J Pharmacol 1994, 271: 273-282.

34. Martin RJ, Clark CL, Trailovic SM, Robertson AP: Oxantel is an N-type (methyridine and nicotine) agonist not an L-type (levamisole and pyrantel) agonist: classification of cholinergic anthelmintics in Ascaris. Int J Parasitol 2004, 34: 1083-1090.

35. Dale VM, Martin RJ: Oxantel-activated single channel currents in the muscle membrane of Ascaris suum. Parasitology 1995, 110 ( Pt 4): 437-448.

36. Bamgbose SO, Marquis VO, Salako LA: Some pharmacological effects of the nematocide, morantel. Br J Pharmacol 1973, 47: 117-123.

37. Cornwell RL, Blore MA: Anthelmintic activity of pyrantel and morantel against adult and larval stages of Nippostrongylus brasiliensis and Nematospiroides dubius. Ann Trop Med Parasitol 1970, 64: 525-531.

38. Evans AM, Martin RJ: Activation and cooperative multi-ion block of single nicotinicacetylcholine channel currents of Ascaris muscle by the tetrahydropyrimidine anthelmintic, morantel. Br J Pharmacol 1996, 118: 1127-1140.

39. Courtot E, Charvet CL, Beech RN, Harmache A, Wolstenholme AJ, Holden-Dye L, O'Connor V, Peineau N, Woods DJ, Neveu C: Functional characterization of a novel 
class of morantel-sensitive acetylcholine receptors in nematodes. PLoS Pathog 2015, 11: e1005267.

40. Abongwa M, Baber KE, Martin RJ, Robertson AP: The cholinomimetic morantel as an open channel blocker of the Ascaris suum ACR-16 nAChR. Invert Neurosci 2016, 16: 10.

41. Burg RW, Miller BM, Baker EE, Birnbaum J, Currie SA, Hartman R, Kong YL, Monaghan RL, Olson G, Putter I, Tunac JB, Wallick H, Stapley EO, Oiwa R, Omura S: Avermectins, new family of potent anthelmintic agents: producing organism and fermentation. Antimicrob Agents Chemother 1979, 15: 361-367.

42. Takiguchi Y, Mishima H, Okuda M, Terao M, Aoki A, Fukuda R: Milbemycins, a new family of macrolide antibiotics: fermentation, isolation and physico-chemical properties. J Antibiot (Tokyo) 1980, 33: 1120-1127.

43. Takiguchi Y, Ono M, Muramatsu S, Ide J, Mishima H, Terao M: Milbemycins, a new family of macrolide antibiotics. Fermentation, isolation and physico-chemical properties of milbemycins D, E, F, G, and H. J Antibiot (Tokyo) 1983, 36: 502-508.

44. Davies HG, Green RH: Avermectins and milbemycins. Nat Prod Rep 1986, 3: 87-121.

45. McKellar QA, Benchaoui HA: Avermectins and milbemycins. J Vet Pharmacol Ther 1996, 19: 331-351.

46. Cully DF, Vassilatis DK, Liu KK, Paress PS, Van der Ploeg LH, Schaeffer JM, Arena JP: Cloning of an avermectin-sensitive glutamate-gated chloride channel from Caenorhabditis elegans. Nature 1994, 371: 707-711.

47. Wolstenholme AJ, Rogers AT: Glutamate-gated chloride channels and the mode of action of the avermectin/milbemycin anthelmintics. Parasitology 2005, 131 Suppl: S85-95.

48. Abongwa M, Buxton SK, Robertson AP, Martin RJ: Curiouser and curiouser: the macrocyclic lactone, abamectin, is also a potent inhibitor of pyrantel/tribendimidine nicotinic acetylcholine receptors of gastro-intestinal worms. PLoS One 2016, 11: e0146854.

49. Holden-Dye L, Walker RJ: Avermectin and avermectin derivatives are antagonists at the 4-aminobutyric acid (GABA) receptor on the somatic muscle cells of Ascaris; is this the site of anthelmintic action? Parasitology. 1990, Oct;101 Pt 2:265-271.

50. Puttachary S, Trailovic SM, Robertson AP, Thompson DP, Woods DJ, Martin RJ: Derquantel and abamectin: effects and interactions on isolated tissues of Ascaris suum. Mol Biochem Parasitol 2013, 188: 79-86.

51. Ottesen EA, Campbell WC: Ivermectin in human medicine. J Antimicrob Chemother 1994, 34: 195-203.

52. Shan Q, Haddrill JL, Lynch JW: Ivermectin, an unconventional agonist of the glycine receptor chloride channel. J Biol Chem 2001, 276: 12556-12564.

53. Krause RM, Buisson B, Bertrand S, Corringer PJ, Galzi JL, Changeux JP, Bertrand D: Ivermectin: a positive allosteric effector of the alpha7 neuronal nicotinic acetylcholine receptor. Mol Pharmacol 1998, 53: 283-294.

54. Ducray P, Gauvry N, Pautrat F, Goebel T, Fruechtel J, Desaules Y, Weber SS, Bouvier J, Wagner T, Froelich O, Kaminsky R: Discovery of amino-acetonitrile derivatives, a new class of synthetic anthelmintic compounds. Bioorg Med Chem Lett 2008, 18: 2935-2938.

55. Kaminsky R, Ducray P, Jung M, Clover R, Rufener L, Bouvier J, Weber SS, Wenger A, Wieland-Berghausen S, Goebel T, Gauvry N, Pautrat F, Skripsky T, Froelich O, KomoinOka C, Westlund B, Sluder A, Mäser P: A new class of anthelmintics effective against drugresistant nematodes. Nature 2008a, 452: 176-180. 
56. Kaminsky R, Gauvry N, Schorderet Weber S, Skripsky T, Bouvier J, Wenger A, Schroeder F, Desaules Y, Hotz R, Goebel T, Hosking BC, Pautrat F, Wieland-Berghausen S, Ducray P: Identification of the amino-acetonitrile derivative monepantel (AAD 1566) as a new anthelmintic drug development candidate. Parasitol Res 2008b, 103: 931-939.

57. Baur R, Beech R, Sigel E, Rufener L: Monepantel irreversibly binds to and opens Haemonchus contortus MPTL-1 and Caenorbabditis elegans ACR-20 receptors. Mol Pharmacol 2015, 87: 96102.

58. Lecova L, Stuchlikova L, Prchal L, Skalova L: Monepantel: the most studied new anthelmintic drug of recent years. Parasitology 2014, 141: 1686-1698.

59. Rufener L, Bedoni N, Baur R, Rey S, Glauser DA, Bouvier J, Beech R, Sigel E, Puoti A: acr-23 Encodes a monepantel-sensitive channel in Caenorbabditis elegans. PLoS Pathog 2013, 9: e1003524.

60. Rufener L, Maser P, Roditi I, Kaminsky R. Haemonchus contortus acetylcholine receptors of the DEG-3 subfamily and their role in sensitivity to monepantel. PLoS Pathog 2009, 5: e1000380.

61. Lee BH, Clothier MF, Dutton FE, Nelson SJ, Johnson SS, Thompson DP, Geary TG, Whaley HD, Haber CL, Marshall VP, Kornis GI, McNally PL, Ciadella JI, Martin DG, Bowman JW, Baker CA, Coscarelli EM, Alexander-Bowman SJ, Davis JP, Zinser EW, Wiley V, Lipton MF, Mauragis MAMarcfortine and paraherquamide class of anthelmintics: discovery of PNU-141962. Curr Top Med Chem 2002, 2: 779-793.

62. Little PR, Hodge A, Maeder SJ, Wirtherle NC, Nicholas DR, Cox GG, Conder GA: Efficacy of a combined oral formulation of derquantel-abamectin against the adult and larval stages of nematodes in sheep, including anthelmintic-resistant strains. Vet Parasitol 2011, 181: 180-193.

63. Rufener L, Baur R, Kaminsky R, Maser P, Sigel E: Monepantel allosterically activates DEG3/DES-2 channels of the gastrointestinal nematode Haemonchus contortus. Mol Pharmacol 2010, 78: 895-902.

64. Robertson AP, Clark CL, Burns TA, Thompson DP, Geary TG, Trailovic SM, Martin RJ: Paraherquamide and 2-deoxy-paraherquamide distinguish cholinergic receptor subtypes in Ascaris muscle. J Pharmacol Exp Ther 2002, 302: 853-860.

65. Geurden T, Hodge A, Noe L, Winstanley D, Bartley DJ, Taylor M, Morgan C, Fraser SJ, Maeder S, Bartram D: The efficacy of a combined oral formulation of derquantelabamectin against anthelmintic resistant gastro-intestinal nematodes of sheep in the UK. Vet Parasitol 2012, 189: 308-316.

66. Anderson N, Martin PJ, Jarrett RG: Mixtures of anthelmintics: a strategy against resistance. Aust Vet J 1988, 65: 62-64.

67. Bartram DJ, Leathwick DM, Taylor MA, Geurden T, Maeder SJ: The role of combination anthelmintic formulations in the sustainable control of sheep nematodes. Vet Parasitol 2012, 186: 151-158.

68. Sasaki T, Takagi M, Yaguchi T, Miyadoh S, Okada T, Koyama M: A new anthelmintic cyclodepsipeptide, PF1022A. J Antibiot (Tokyo) 1992, 45: 692-697.

69. Harder A, Schmitt-Wrede HP, Krucken J, Marinovski P, Wunderlich F, Willson J, Amliwala K, Holden-Dye L, Walker R: Cyclooctadepsipeptides--an anthelmintically active class of compounds exhibiting a novel mode of action. Int J Antimicrob Agents 2003, 22: 318-331.

70. Harder A, Holden-Dye L, Walker R, Wunderlich F: Mechanisms of action of emodepside. Parasitol Res 2005, 97 Suppl 1: S1-10. 
71. Harder A, von Samson-Himmelstjerna G: Activity of the cyclic depsipeptide emodepside (BAY 44-4400) against larval and adult stages of nematodes in rodents and the influence on worm survival. Parasitol Res 2001, 87: 924-928.

72. Kulke D, Krucken J, Demeler J, Harder A, Mehlhorn H, von Samson-Himmelstjerna G: In vitro efficacy of cyclooctadepsipepdtides and aminophenylamidines alone and in combination against third-stage larvae and adult worms of Nippostrongylus brasiliensis and first-stage larvae of Trichinella spiralis. Parasitol Res 2013, 112: 335-345.

73. Kulke D, Krucken J, Harder A, Krebber R, Fraatz K, Mehlhorn H, von SamsonHimmelstjerna G: In vivo efficacy of PF1022A and nicotinic acetylcholine receptor agonists alone and in combination against Nippostrongylus brasiliensis. Parasitology 2013, 140: 1252 1265.

74. Kulke D, Krucken J, Harder A, von Samson-Himmelstjerna G: Efficacy of cyclooctadepsipeptides and aminophenylamidines against larval, immature and mature adult stages of a parasitologically characterized trichurosis model in mice. PLoS Negl Trop Dis 2014, 8: e2698.

75. Zahner H, Taubert A, Harder A, von Samson-Himmelstjerna G. Effects of Bay 44-4400, a new cyclodepsipeptide, on developing stages of filariae (Acanthocheilonema viteae, Brugia malayi, Litomosoides sigmodontis) in the rodent Mastomys coucha. Acta Trop 2001, 80: 19-28.

76. Zahner H, Taubert A, Harder A, von Samson-Himmelstjerna G: Filaricidal efficacy of anthelmintically active cyclodepsipeptides. Int J Parasitol 2001b, 31: 1515-1522.

77. von Samson-Himmelstjerna G, Harder A, Sangster NC, Coles GC: Efficacy of two cyclooctadepsipeptides, PF1022A and emodepside, against anthelmintic-resistant nematodes in sheep and cattle. Parasitology 2005, 130: 343-347.

78. Holden-Dye L, O'Connor V, Hopper NA, Walker RJ, Harder A, Bull K, Guest M: SLO, SLO, quick, quick, slow: calcium-activated potassium channels as regulators of Caenorbabditis elegans behaviour and targets for anthelmintics. Invert Neurosci 2007, 7: 199-208.

79. Krucken J, Harder A, Jeschke P, Holden-Dye L, O'Connor V, Welz C, von SamsonHimmelstjerna G: Anthelmintic cyclcooctadepsipeptides: complex in structure and mode of action. Trends Parasitol 2012, 28: 385-394.

80. Martin RJ, Buxton SK, Neveu C, Charvet CL, Robertson AP: Emodepside and SL0-1 potassium channels: a review. Exp Parasitol 2012 132: 40-46.

81. Guest M, Bull K, Walker RJ, Amliwala K, O’Connor V, Harder A, Holden-Dye L, Hopper NA: The calcium-activated potassium channel, SLO-1, is required for the action of the novel cyclo-octadepsipeptide anthelmintic, emodepside, in Caenorbabditis elegans. Int J Parasitol 2007, 37: 1577-1588.

82. Willson J, Amliwala K, Davis A, Cook A, Cuttle MF, Kriek N, Hopper NA, O’Connor V, Harder A, Walker RJ, Holden-Dye L: Latrotoxin receptor signaling engages the UNC-13dependent vesicle-priming pathway in C. elegans. Curr Biol 2004, 14: 1374-1379.

83. Crisford A, Ebbinghaus-Kintscher U, Schoenhense E, Harder A, Raming K, O'Kelly I, Ndukwe K, O'Connor V, Walker RJ, Holden-Dye L: The cyclooctadepsipeptide anthelmintic emodepside differentially modulates nematode, insect and human calciumactivated potassium (SLO) channel alpha subunits. PLoS Negl Trop Dis 2015, 9: e0004062.

84. Kulke D, Krucken J, Welz C, von Samson-Himmelstjerna G, Harder A: In vivo efficacy of the anthelmintic tribendimidine against the cestode Hymenolepis microstoma in a controlled laboratory trial. Acta Trop 2012, 123: 78-84. 
85. Ren HN, Cheng BZ, Zhuang ZN: Experimental therapeutic efficacy of a new antihookworm drug, tribendimidin. Zhongguo Ji Sheng Chong Xue Yu Ji Sheng Chong Bing Za Zhi 1987, 5: 262-264.

86. Xiao SH, Hui-Ming W, Tanner M, Utzinger J, Chong W. Tribendimidine: a promising, safe and broad-spectrum anthelmintic agent from China. Acta Trop 2005, 94: 1-14.

87. Bergquist R: Tribendimidine: great expectations. Lancet Infect Dis 2016, 16: 1089-1091.

88. Keiser J, Shu-Hua X, Chollet J, Tanner M, Utzinger J: Evaluation of the in vivo activity of tribendimidine against Schistosoma mansoni, Fasciola hepatica, Clonorchis sinensis, and Opisthorchis viverrini. Antimicrob Agents Chemother 2007, 51: 1096-1098.

89. Steinmann P, Zhou XN, Du ZW, Jiang JY, Xiao SH, Wu ZX, Zhou H, Utzinger J: Tribendimidine and albendazole for treating soil-transmitted helminths, Strongyloides stercoralis and Taenia spp.: open-label randomized trial. PLoS Negl Trop Dis 2008, 2: e322.

90. Wu ZX, Fang YY, Liu YS: Effect of a novel drug-enteric coated tribendimidine in the treatment of intestinal nematode infections. Zhongguo Ji Sheng Chong Xue Yu Ji Sheng Chong Bing Za Zhi 2006, 24: 23-26.

91. Xiao SH, Xue J, Xu LL, Zheng Q, Qiang HQ, Zhang YN: The in vitro and in vivo effect of tribendimidine and its metabolites against Clonorchis sinensis. Parasitol Res 2009, 105: 1497-1507.

92. Xu LL, Jiang B, Duan JH, Zhuang SF, Liu YC, Zhu SQ, ZhangLP, Zhang HB, Xiao SH, Zhou XN: Efficacy and safety of praziquantel, tribendimidine and mebendazole in patients with co-infection of Clonorchis sinensis and other helminths. PLoS Negl Trop Dis 2014, 8: e3046.

93. Xiao SH, Utzinger J, Tanner M, Keiser J, Xue J: Advances with the Chinese anthelminthic drug tribendimidine in clinical trials and laboratory investigations. Acta Trop 2013, 126: 115-126.

94. Hu Y, Xiao SH, Aroian RV: The new anthelmintic tribendimidine is an L-type (levamisole and pyrantel) nicotinic acetylcholine receptor agonist. PLoS Negl Trop Dis 2009, 3: e499.

95. Robertson AP, Puttachary S, Buxton SK, Martin RJ: Tribendimidine: mode of action and nAChR subtype selectivity in Ascaris and Oesophagostomum. PLoS Negl Trop Dis 2015, 9: e0003495.

96. Coles GC, Jackson F, Pomroy WE, Prichard RK, von Samson-Himmelstjerna G, Silvestre A, Taylor MA, Vercruysse J: The detection of anthelmintic resistance in nematodes of veterinary importance. Vet Parasitol 2006, 136(3-4):167-185.

97. Geerts S, Gryseels B: Drug resistance in human helminths: current situation and lessons from livestock. Clin Microbiol Rev 2000, 13(2):207-222.

98. Geerts S1, Gryseels B: Anthelmintic resistance in human helminths: a review. Trop Med Int Health 2001, 6(11):915-921.

99. Sangster NC: Anthelmintic resistance: past, present and future. Int J Parasitol 1999, 29(1):115-124.

100. Conway DP: Variance in the effectivenes of thiabedazole against Haemonchus contortus in sheep. Am J Vet Res 1964, 25:844-846.

101. Kaplan RM: Drug resistance in nematodes of veterinary importance: a status report. Trends Parasitol 2004, 20(10):477-481.

102. Kaplan RM, Vidyashankar AN: An inconvenient truth: global worming and anthelmintic resistance. Vet Parasitol 2012, 186(1-2):70-78.

103. Waller PJ: Anthelmintic resistance. Vet Parasitol 1997, 72(3-4):391-405. 
104. Gilleard JS: Understanding anthelmintic resistance: the need for genomics and genetics. Int J Parasitol 2006, 36(12):1227-1239.

105.Jabbar A, Iqbal Z, Kerboeuf D, Muhammad G, Khan MN, Afaq M: Anthelmintic resistance: the state of play revisited. Life Sci 2006, 25;79(26):2413-2431.

106.James CE, Hudson AL, Davey MW: Drug resistance mechanisms in helminths: is it survival of the fittest? Trends Parasitol 2009, 25(7):328-335.

107.Sangster NC, Gill J: Pharmacology of anthelmintic resistance. Parasitol Today 1999, 15(4):141-146.

108. Wolstenholme AJ, Fairweather I, Prichard R, von Samson-Himmelstjerna G, Sangster NC: Drug resistance in veterinary helminths. Trends Parasitol 2004, 20(10):469-476.

109. Coles GC: Anthelmintic resistance--looking to the future: a UK perspective. Res Vet Sci. 2005, 78(2):99-108.

110.Leathwick DM: Modelling the benefits of a new class of anthelmintic in combination. Vet Parasitol 2012, 186(1-2):93-100.

111. Shalaby HA: Anthelmintics resistance; how to overcome it? Iran J Parasitol 2013, 8(1):1832.

\section{KRATAK PRIKAZ NAČINA DELOVANJA ANTINEMATODALNIH LEKOVA}

\section{ABONGWA Melanie, MARTIN Richard J., ROBERTSON Alan P.}

Anthelmintici su jedni od najčešće upotrebljavanih lekova u veterinarskoj medicini. U ovom radu su opisani mehanizmi delovanja nekih od ovih preparata na nematode. İspitivanjima su obuhvaćeni neki od starijih preparata: benzimidazoli, holinergični agonisti i makrociklični laktoni. Takođe, ispitivani su noviji preparati uključujući emodepside, derquantel i tribandimidin. U odsustvu vakcina, kontrola većine vrsta parazita nematoda, nastaviće da se obavlja primenom anthelmintika. Kao posledica, neophodno je da se neprestano prati i uočava mogućnost stvaranja rezistentnih populacija parazita. Pošto je razvoj rezistencije skoro neizostavan, postoji stalna i jaka potreba da se u potpunosti razume način delovanja ovih preparata. Isto tako, neophodno je da se identifikuju novi ciljevi lekova kao i novi lekovi, a sa ciljem stalne i efikasne kontrole nematoda. 